\title{
Marketing in High-Tech Start-Ups: overcoming the liability of newness in Israel
}

\author{
Schaul Chorev, Alistair R. Anderson* \\ Charles P. Skene Centre for Entrepreneurship, Aberdeen Business School, The Robert \\ Gordon University, Garthdee Road, Aberdeen AB10 7QE, Scotland, UK
}

Address for correspondence:

Alistair R. Anderson

Charles P. Skene Centre for Entrepreneurship

Aberdeen Business School

The Robert Gordon University

Garthdee Road

Aberdeen AB10 7QE

Scotland UK

Email: schaulc@yahoo.com; a.r.anderson@rgu.ac.uk

Telephone: +44 (0)1224 263883

Fax: +44 (0)1224 263870 
Marketing in High-Tech Start-Ups: overcoming the liability of newness in Israel

\begin{abstract}
For new companies in general, marketing is a critical issue. However, many high tech start ups face particular problems associated with marketing. They may have a product, rather than a customer focus; they may lack marketing experience and may even neglect marketing to focus on developing a better product. They also work in an ambiguous environment; a new, or yet to be established market, unclear application and often a need to internationalise rapidly. The purpose of this paper is thus to try to capture what experienced experts have found to work best in these difficult conditions. Our study is based in Israel, but may have lessons for many other small countries. We employed a multiple stage methodology, seeking expert views; analysing and consolidating then refining these. Our contribution is the condensed wisdom of some 80 of the key players in new Israeli high tech firms. The paper shows how some aspects are vital for success, but also explores the roles played by the various aspects of marketing.
\end{abstract}

Keywords: marketing, high-tech, start-up, success, Israel 


\section{Introduction}

High-tech in general, and high-tech start-ups in particular, have becomes a major factor influencing the world economy (Tadmor,1997). However, start-up companies developing high-technology products face particular problems associated with their products and their own newness. The technologies are often developing; applications may be unclear and the markets not yet established. Moreover, the technological focus necessary to develop the product may obscure the need to establish customers for the product. Internally, new companies may also lack expertise in marketing. Consequently many of the problems associated with high-tech new firms become manifest in the area of marketing. The purpose of this paper is to explore the issue of viable marketing practices in new high-tech companies to consider approaches and elements which could enhance the prospects of their success. The implementation of marketing in uncertain conditions, and with serious resource constraints, makes this subject particularly important in new ventures.

Our study is based in Israel where high-tech has a particular salience because of the economic and political need to develop successful exporting high-technology firms. We collected data from experts about their experiences of what marketing practices worked best and collated the synthesised results for expert review. These informed best practices, when properly grounded in the experiences of both successful and unsuccessful entrepreneurs, may provide a template to guide the formation and operation of new and growing high-tech companies. Although there is evidence for the increasing awareness about the need for marketing in high-tech industries (Dhanani, O'Shaughnessy and Louw 1997), the literature offers very little empirical advice about success issues in high-tech start-ups in general, and even less data is available for those who need to start the business with a global approach from the outset. Consequently, the contribution of this paper is twofold, first to collate the experiences of practitioners and secondly, to present this as a synthesis of practical wisdom. Accordingly, we 
develop a template of key issues which will enable start-up managers to direct their attention to the critical elements of marketing apparently required for new venture success.

In this way our study captures the implicit knowledge embedded in the experiences of entrepreneurs and others who are, or have been, engaged in the realities of high-tech venture marketing. We employed a multiple stage study consisting of multiple interviews to develop a preliminary model, then tested and refined by pilot and a final survey. The nature of this study thus provides some empirical evidence about the utility and application of factors deemed necessary for the successful marketing of high-tech Israeli ventures. The paper begins by considering the role of high-tech ventures for economic growth generally and in Israel in particular. We then examine the specific marketing problems associated with high-tech new ventures. After explaining our methodology, which builds upon the existing literature to identify critical factors, we present our initial findings as a tentative model which we operationalised in the pilot study. A questionnaire, revised in the light of the initial findings, was completed by some 80 experts. From these data we arrive at our final results.

\section{Globalisation, internationalisation and entrepreneurial high-tech}

Although small in number compared to other types of firms, high-tech ventures generate a disproportionate share of wealth and new jobs. Early economists, for example Schumpeter (1934) and Solow (1970), recognized the importance of innovation as catalyzing markets and creating economic growth. More recently the focus has been on technology as the primary force behind driving up rising standards of living (Grossman and Helpman, 1994). Indeed, Tapscott (1996) argues that technological innovation will determine the success of nations in the future. The indications are therefore, that high-tech ventures are a primary driver of the new economy and the associated level of growth. Within high-tech, a critical sector is the high-tech start-up company. These new companies are seen as the harbingers of prosperity because they offer prospects of high growth and profitability. In the specifics of place, new 
high-tech start-ups thus offer a means to achieve the Israeli national goal of economical independence.

There is sound evidence that over the past ten years, public policy and private initiative have stimulated impressive growth rates of Israeli high-tech entrepreneurship. Indeed, the Israeli high-tech industry has raised more capital than any other sector in Israel. This explosive growth of Israel's high-tech sector has attracted widespread attention. For example, in its survey of VC firms, Wired Magazine (July 2000) placed Israel in the top four of the world's high-technology hot spots; one place lower than Silicon Valley, on a par with Boston and Stockholm, but ahead of London, Helsinki and Bangalore. In the decade from 1990-2000, the high-tech portion of the total Israeli GNP increased more than two and half times, from $8 \%$ to $21 \%$ in 2000; employment tripled, while export high-tech volume grew by a factor of 18 . In 2001 and 2002, although high-tech was in deep crisis, it still contributed about 50\% of Israeli export value (Israel Export Institute, 2002).

In general terms, Roberts (1991a) suggests that the growth rate of new firms and small firms is systematically greater than for large and established incumbents. He asserts that there is evidence for a positive correlation between countries that have experienced an increased role of entrepreneurial activity and higher rates of subsequent growth. The Global Entrepreneurship Monitor (GEM, 2003) finds that there is a statistically significant positive association between national economic growth and national level of entrepreneurship. Both Carre and Thurik (1997) and Audretsch, Carree, Van Stel, and Thurik (2000) find that there has been a reward in terms of economic growth for countries that have gained a greater share of smaller firms. Lerner and Avrahami $(1999,2002)$ in their GEM study of Israel, conclude that there is a strong relationship between entrepreneurial activities, defined as startup activities, and economic growth. Together with the USA and Canada, Israel leads the global indices for the level of entrepreneurship as indicated by the average business rate per 
10,000 of population. Israel's level is 6.9 compared to 3.4 in Italy and Great Britain and 1.8 in Japan, France, Germany, Finland and Denmark (Lerner and Avrahami, 1999).

Israel has few natural resources, but enjoys a large pool of technologically skilled labour including a high percentage of scientists and engineers as a proportion of the population. Business Week (3/2/97) reports on this unusually high concentration of skilled professionals. Israel has approximately 130 scientists and engineers for every 10,000 workers. This compares with 80 and 75 in the U.S. and Japan, respectively. Moreover, at 3.5\%, it has the greatest R\&D expenditure in the world as a percentage of GDP (Traston, Sarusi, Kochavi, Zisapel and Ayalon, 2002) as well as the highest number of start-ups in the world in relation to the population size. The high-tech sector growth rate is the highest of all industrial sectors. During the first half of 2000 the high-tech growth rate was $12 \%$, while the conventional industry growth rate was only $2 \%$ (Haaretz newspaper, 29.6.00). At the end of 2000, hightech export, amounting to $\$ 15$ billion, contributed $74 \%$ of industrial export. High-tech contribution to GNP growth was about $75 \%$, while high-tech enterprises provided $36 \%$ of GNP (Israel Central Bureau of Statistics - ICBS, 2001). Yet Israel is a small country with a very limited domestic market for high-tech products. Furthermore it has many security problems. These factors force the "isolated" Israeli high-tech industry to rely on overseas markets. Consequently international marketing becomes a key issue for new high-tech success. Whilst we have presented the specific Israeli case, Burgel and Murray (2000) argue that the emergence of entrepreneurial start-ups with an international outlook from initiation, dubbed "born global" (Knight and Cavusgil 1996) are becoming more common. For Oviatt and McDougall (1994) these "international new ventures" are merely a manifestation of the globalised world.

\section{Marketing issues in new high-tech ventures}


Whilst high-tech firms have traditionally depended on their unique technological competitive advantage, it is increasingly difficult to maintain competitiveness by depending solely on technological advantage (Davidow, 1988; Davis, Fusfeld, Scriven and Tritle 2001; Traynor and Traynor, 1994, 1997). It is now clear (Traynor and Traynor, 2004:461) that marketing efforts are now as important, if not more important, than reliance on state-of-the-art technology. Marketing is a critical issue, in part because of the risks associated with hightech. Meldrum (1995) sees the risk for customers magnified by the uncertainties associated with a new technology. For suppliers, uncertainty exists because of a lack of experience in selling, delivering and supporting products. Moreover, since such technology is new to the market it is unlikely to be an accepted solution for the problem that it has been designed to solve. Thus young high-tech ventures invoke a high degree of the risk associated with leading edge technologies and of newly born or yet to be born markets.

Christensen (1997) suggests that one of the best opportunities for young ventures is to enter a new market with a destructive technology. Such markets, he argues, are usually neglected by the main players who focus on serving their present customers with sustaining innovations. This bold marketing strategy discounts the nature of entirely new markets which involve great risk due to the lack of information about the market. Customers don't yet exist, and apparently potential customers might provide misleading market observations about products they have never seen or used. Nonetheless, the rapid pace of high-tech markets often compel the new and small enterprises to embrace risk to develop new products before markets are even clearly defined, far less established.

That said, high-tech as a sector lacks a precise and universally accepted definition (Oakey, Rothwell and Cooper, 1988). However, for practical purposes, a high-tech industry has been generally defined as one whose business activities are heavily dependent upon innovation in science and technology (Medcof, 1999). The degree of radical innovation in the firm has been 
identified as a measure of high-technology, often associated by a radically new product or process that is introduced to the market with a first-mover advantage (Ali, 1994). High-tech ventures invest more heavily in $R \& D$ activities, employ a higher percentage of engineers and scientists, offer innovative technologically advanced products, typically with complex designs and configurations, are dynamic with high rates of change and have short product development cycles and typically enjoy short and volatile lives (Oakey et al., 1988; Covin and Slevin, 1991; Reeble, 1990; Grunewald and Vernon, 1988).

Whilst technology may be seen as the driver of the high-tech start-up, it is well established that lack of technology is not an important factor in failure (Cunningham, 2000). The probable reason is that most high-tech start-up entrepreneurs have a strong technological background and base the start-up on a unique technological idea. However, this technological focus may cause them to pay less attention, combined with a lack of confidence, to marketing (MacInnes and Helsop, 1990). Consequently, underperformance in marketing is recognized as a main reason for failure in the vast majority of failed start-ups (Meier, 1998). Moreover, as one of our respondents, the founder of an Israeli successful start-up (Schema) explains, a start-up has to be successful from the outset. "A start-up seldom gets a second chance. If you don't hit the Bull between his eyes, you pass by in the dark with nobody even noticing that you have ever been there." Yuval Davidor, Schema founder, 2003.

Taken together we can see that the marketing environment and issues about the most suitable marketing methods is problematic for new high-tech firms. Gardner, Johnson, Moonkyu and Wilkinson (2000) consider the unique characteristics to be; earlier stage of the industry life cycle; greater degree of turbulence; higher product differentiation; higher market growth rate; shorter expected life cycle; more visible future for technology; easier entry into the market; more diverse suppliers and a higher level of consumer involvement in purchase decisions. Mohr (2001) describes the high-tech marketing environment as containing three main 
domains: market uncertainty, technological uncertainty and competition volatility. These domains and key issues are described in figure 1.

Fig. 1: The high-tech marketing elements and issues

\section{- Insert Fig. 1. about here please -}

Consequently dealing with this manifest uncertainty and volatility presents a major marketing problem for new high-tech firms. To address this issue our study attempts to capture the knowledge and experience of practitioners who are experts in the field. Next, we outline our methodology.

\section{Research design and methodology}

Our objective was to first identify key factors in high-tech marketing then to seek the opinion of practical experts about their importance, impact and ranking. Our preliminary identification of these factors was based on the academic literature. This was then modified with the data generated by interviewing experts to create an initial model. The model was then operationalised in a survey. The resulting data were then subjected to a final Delphi type scrutiny by selected experts. The stages of the study are described below:

Phase Procedure

$1 \quad$ Literature review

$2 \quad$ Interviews and discussions

$3 \quad$ Pilot survey

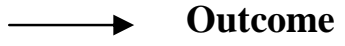

Identification of the main marketing issues related to in high-tech start-up success.

Develop the literature findings with respondents' contextualised practical experience.

Test and revision of the survey instrument. 
$4 \quad$ Survey by questionnaire

5

Delphi study

$6 \quad$ Synthesis of data
Data from both open and closed responses analysed and fitted into revised model

Report on the utility, accuracy and comprehensiveness of the model

Conclusions.

Table 1, Phases of the research process

The first phase, the literature review, established key variables that might influence the marketing success of high-tech start-up companies; some were generic, others unique to Israel. The second phase involved 12 in-depth personal interviews with recognized leaders in the Israeli high-tech start-up community, reflecting Yin's (2003) point that interviews are the preferred strategy when "how" or "why" questions are posed within a real-life context. The respondents were a purposeful sample, selected on the basis of our understanding of their expert role. We did not intend this to be a representative sample; rather our intention was to tap into a well informed and theoretically rich sample frame. Respondents were thus selected on the basis of our knowledge about key players. They included leading managers of startups. This group were engaged in diverse fields of activity and involved in different stages of company life cycles. To broaden our understanding we also interviewed two VC investors who belonged to two of the leading VC organisations in Israel and one angel who has invested tens of millions of dollars in high tech start ups. We felt that these respondents were able to reflect upon different aspects of the start-up environment. This industry sample consisted of managers and investors involved with:

- Three companies originally considered to be very promising ventures, valued at their peak in excess of $\$ 100$ million, but now closed; ( This group represents "failed" ventures)

- One enterprise focusing on a small niche market, striving for profitability with no plans or realistic opportunity for fast growth in the near future; (This represents "struggling" ventures) 
- Three ventures currently in operation (i.e. existing for more than six years) and hoping to prosper in the near future; (This group represents "delayed successes")

- Three ventures which have been sold- one to a large Israeli company, one to a foreign company and a third to a US organization; (This group represents successful exits)

In addition, data were collected by analysing observations of senior persons actively involved in the high-tech start-up community; follow-up of relevant national newspapers articles and by participating in professional workshops and seminars dealing with high-tech. From these various observations, our provisional working model was constructed.

The final questionnaire was interested in general success factors, but included marketing as one of the key topics. The closed type questions were augmented by open-ended questions to tap into different types of responses; to enquire about issues unsuited to closed questions and to identify items that had not been anticipated. The final questionnaires were distributed via personal contacts or with the assistance of organizations such as the Israeli Center of Management and the Israeli Institute Fostering Entrepreneurship. 80\% of the responses came from or through personal contacts. In total, the survey was completed by the CEOs or VPs of 70 high-technology start-up companies and by 10 Venture Capitalists or consultants. The data were first analyzed qualitatively and the different issues delineated and categorized. This was followed by a statistical analysis of the findings to rank the perceived level of importance. From these data we produced a model which we validated by the Delphi method. We asked $50 \%$ of the respondents from our main survey to consider the model and rank it again. The Delphi Methods use of a panel of experts proposes that the group will converge toward the "best" response through this consensus process (Linstone and Turoff, 1975). For this Delphi stage we had 16 responses, a $40 \%$ response rate. The final step was a synthetic conclusion, informed by theory but grounded in the empirical study.

\section{Important elements of marketing high-tech}




\section{Marketing strategies}

We comment first on the key elements in marketing as reported in the literature and as amended by the observations of our first group of experts. This section is followed by our survey data.

The literature proposes a market-driven capability, referred to as "market orientation" and defined as a firm's ability to track and respond to ongoing changes in the marketplace through intelligence generation and information dissemination activities (Jaworski and Kohli, 1993; Slater and Narver, 1999). Market-oriented businesses usually seek to develop a systemic process through which firms recognize opportunities by identifying customers' expressed and latent needs and market trends and develop superior solutions to meet them (Cooper, 1979; Kohli and Jaworski, 1990; Day, 1999; Slater and Narver 1995, 1999; Jaworski and Kohli, 1993). While some researchers argue that firms with a strong market orientation may overemphasize current customer needs, possibly overlooking future products and growth opportunities (Christensen and Bower, 1996), other researchers, such as Slater and Narver (1998) disagree. Cooper (1994) identifies strong market orientation, a market driven and customer focused "new product process" as a key success factor for new products. Rosen, Schroeder and Purinton (1998) argue that there are specific features of high-tech markets that are believed to distinguish them from other product categories. If so, then marketing strategy for high-tech should be different (Gardner et al. 2000), because effective marketing requires knowledge about the unique characteristics of high-tech.

The concept of targeted customers with a solid marketing strategy is important for any business but even more so for a high-tech start-up.. Roberts (1991b) explains that strategic evolutions are manifest in maintaining focus on products and markets with some degree of technological aggressiveness. Davidow (1986) maintains that successful products focus on a technology-based, market-focused strategy, accompanied by a strong support to the distribution channels instead of a technology dominant strategy. Cooper (1979) emphasises 
the importance of market knowledge and marketing proficiency in terms of market assessment, market studies and market testing and also underlines the understanding of market aspects such as price sensitivities, buyer behaviour, market potential and competition as well as having a strong sales force and distribution effort, well-targeted at launch. Identifying market needs requires a combination of marketing and technical skills. Cooper and Kleinschmidt (1990), Gardner (1990a, 1990b) and Gardner et. al. (2000) all assert that the variables related to marketing effectiveness, market potential and market structure are critical for both original and reformulated new industrial products. A young venture competing in this rapidly shifting environment has to closely follow the change of priorities and needs of the market (Cooper and Kleinschmidt, 1990).

In response to these priorities the literature emphasises that the marketing plan is one of the vital elements for business success (Baker, Addams and Davis 1993, McDonald 1989). But engineering focused groups may resist marketing-led requirements since they believe that they alone have a close understanding of the technology. Moreover, marketing planning may establish goals that cannot be attained due to technical barriers. Past marketing efforts may have been unsuccessful because of schedule pressures and limited resources. Such problems can create resistance that may reduce the role of marketing to the level of developing brochures, writing press releases and running trade-shows (Kunda 1992; Dutta, Narasimhan and Rajiv, 1999).

Market analysis should be the first step to finding customers (Easingwood and Koustelos, 2000). Qualitative and quantitative analytical techniques can identify customer groupings with the greatest potential. Segmentation is a marketing activity that provides information about growth rates, buyer motivation, competitive offerings and costs of selling for various segments. But market research was found in recent studies (Dhanani et al., 1997; Traynor and Traynor, 2004) as having a relatively low value relative to other marketing tools. 
Our expert respondents confirmed the importance of these points. Strategy in general and the derived ensuing marketing strategy were seen to drive the course of the organization. However as one respondent commented, "With a few exceptions, high-tech start-up CEOs may know technology, but they are clueless about marketing. They simply believe that if they build it, customers will come". (our respondents observations are italicised ) Thus a major fault in many start-ups is the focus on technology and not on opportunities. "The recommendation of "we need more marketing" is rarely greeted enthusiastically in hightech." The majority of high-tech start-ups stem from engineers and scientist who typically believe that a good product will sell. "Start-up leaders frequently don't consider marketing as a profession and founders, who often lack any sort of any marketing background tend to undertake the marketing missions. They talk to the technologists but neglect the need to establish rapport with the decision makers".

A sound marketing strategy based on thorough knowledge of the market intricacies is crucial for success. Focusing is probably a key feature; knowing the markets and then selecting a market niche for products and geography, while continuously updating the marketing strategy are key elements in the marketing strategy. "Marketing is critical and should be staffed with the best professionals and not treated as an area for savings". Respondent emphasised that the venture has to consider the best composition of the marketing team and their geographical location. Moreover, "external consultants can often assist with access to customers and other marketing efforts". Experts recommended "avoid (at least at the outset) products that need to educate the market or those who establish new standards in the markets". These require a lengthy and resource demanding effort. Regulated markets can also pose a great obstacle. "There is a need to support the distribution channels".

For planning, the experts insisted that business plans have to be clear and based on realistic market needs. Industry analysis and SWOT analysis are the basic tools from which to 
construct strategy. Expertise of the core team, diversified knowledge and group harmony are essential for success. "Many of the start-ups constructed during the "Bubble" era were founded by inexperienced young entrepreneurs who lacked both management skills or experience. They often don't appreciate the need to hire adequate managers, thus causing enormous difficulties in the $R \& D$ and marketing processes."

\section{Customer relations}

Much of the literature emphasises the need to get close to customers and to appreciate things from their perspective. Many potential customers are slow to commit to buying anything, let alone a new platform that requires a whole new way of thinking (Reingold, 2001). Customers associate high-tech products with a high level of risk, so constructive marketing should relieve adopter fears and risks (Dhanani et al., 1997). Cooper and Kleinschmidt (1990) propose that customer features such as dissatisfaction with competing products, willingness to try or accept new products, the importance of the purchase are all key factors for new product's success.

Again our experts agreed with the literature. As the CEO of the start-up company Akela says, "The key to this survival strategy is to spend a lot of time talking with customers; you have to make sure your road map lines up with the customer's road map". The respondents noted that for start-ups that are remote from their target markets, it is more difficult to follow customers' real needs and hence they are inclined to assume "we know what the customer needs", which could be a serious mistake. Cultural differences encourage the commonplace habit of skipping and avoiding the "Customers' Voice". Moreover, one respondent argued that "customers are the buyers of the product and without being close to the customers, understanding their needs and implementing their feedback, there is a reduced chance of success". Cultural differences are also important. Overall, "a high level of service is necessary to retain loyal customers". Strategic alliances with key customers, other companies or marketing organizations were noted as often the key for success. They can assist in R\&D and can help bring the complete 
solution to the market in the right time and with the appropriate means. Thus, "securing alliances or cooperation at an early stage could be a major asset for a young venture”.

\section{Research and development}

The development of new technology does not guarantee commercial success (Berry, 1996; Erickson, Magee, Rousel and Saad, 1990; Green, 1995). Many researchers support the notion that there is a need for strong links between the R\&D department and other functional areas (Roberts, 1978, 1979; Wind 1981, 1982; Goupta, Raj and Wilemon, 1986 and Von Hippel 1978). Consequently, effective integration of $R \& D$ and marketing is emphasized for innovation success (Goupta and Wilemon, 1990). There is evidence that linkage problems are common and when these are not resolved, failure is the usual result. Young (1973) and Souder (1977, 1981), for example, note that the failure to integrate R\&D and marketing early in the innovation process is one of the biggest contributors to new product failure.

Although patents are seen as offering a strong competitive advantage by creating entry barriers for competitors, some studies (Traynor and Traynor, 2004; Dhanani et al., 1997) found that patent protection for small high-tech and start-up firms was perceived as less important. A possible reason is that patents do not provide significant advantage in the dynamically changing high-tech environment where technology can rapidly become outdated.

In addition to these points, our experts observed that $R \& D$ should take advantage of the unique technologies and the skilled workforce in Israel. New breakthrough technologies require careful analysis to determine adequate timing for market launch. As one respondent notes, "communication between $R \& D$ and marketing should be monitored and fostered." Overall they recognised that a major flaw of Israeli high-tech start-ups is a lack of a sound link between $\mathrm{R} \& \mathrm{D}$ and marketing. For example "If there is one thing Israeli high-tech companies lack, it is the ability to transform a great technology into a usable product with a suitable human interface”. 


\section{Markets and marketing}

Several scholars (Frenkel, Reiss, Maital, Koschatzky and Grupp, 1994; Steinberg, 1999; Goldman, 2001) emphasise access to overseas markets as essential for the survival of a new enterprise. Moreover a number of studies (Hashai and Almor, 2004; Dvir and Tishler, 1999; Dvir et al. 1997; Lerner and Yeheskel, 2002) consider the uniqueness of Israeli high-tech start-up ventures to make the following points

- Penetration of global markets is essential for survivability and success; but international market needs and behaviours may be unfamiliar and there are different cultures in overseas target markets;

- Typical rapid shifts in the high-tech environment create specific managerial problems;

- Creating alliances or mergers or acquisitions are often required to penetrate foreign markets and to provide a desirable complete solution.

Our experts agreed with these points but added that the location of marketing staff may also be crucial. "Typically, to enter the US market, it is best to consider a local location but the problem increases if markets are sought in Europe and elsewhere”.

\section{Findings from the main survey}

As we discussed earlier, our survey aim was to operationalise the important factors identified from the literature and by our expert panel, then to ask 80 respondents, identified as experienced in the area, about their significance and ranking based on their own knowledge and experiences. The ranking was based on a Likert scale ranging from 1 to 7 , where 7 represents the highest importance. We took the mean scores of all the items' ranking to represents their level of importance. However, there is still a significant difference in the level of importance of the different topics and parameters. This is illustrated by the fact that several of the items received ranking scores of 6.00 or more, up to 6.34 , while the lowest score of is 4.63. This demonstrates that some items are perceived to have a very high importance and relevance for success and some are deemed to have an apparently much lower impact. 


\section{Marketing strategy}

The overall subject of marketing strategy is considered as having a high impact on high-tech start-ups success prospects hence received a high score of 6.17. Figure 2 shows the relative importance attributed to the factors of market strategy. Interestingly, the perceived utility of the product was thought most important, whilst distribution channels were rated least important.

\section{Fig. 2: The main elements of marketing strategy}

\section{- Insert Fig. 2. about here please -}

The items ranked as of high importance in marketing strategy are; the perceived utility of the product, market expertise, the marketing plan, marketing R\&D interface and the penetration of the main markets. These 5 topics scored close to 6 or above. Some respondents enlarged on these points in their answers to our open ended questions. "The perceived utility is a major gauge to assess the real need for the product; The marketing plan is based on strategy but has to be constructed appropriately to reflect the strategy and enabled to execute it properly; The start-up has to know the industry and needs expertise in the market”. Marketing and R\&D relationships are also perceived as very important because, "even in small organisations, we observe a lack of coordination, sometimes driven by personality conflicts". In terms of outcomes, " $R \& D$ is not developing what marketing believes is required for the target market”.

Distribution channels received a low rating, perhaps because many start-ups have limited sales. Most start-ups believe that they have to penetrate the market by themselves and once they have done so, it will be easy to establish the distribution channel. Establishing new 
market standards can be very rewarding, but it contains a high risk and can have a destructive effect on a small start-up and therefore not seen as an important parameter for success. Again our respondents emphasised that "Education of the market to adapt new standards can be a long lasting and excessively resource demanding process for a small start-up”.

Surprisingly, market research was ranked quite low. Most of the respondents who had conducted market research claimed that it didn't provide them with meaningful and useful results that could assist them in formulating the strategy or make other key decisions. We wondered if a possible reason could be that professional market research in overseas markets is expensive and most start-ups prefer to save funds. Thus they may neglect market research or hire a low cost market research company which does not produce the expected results. Moreover, some of the start-ups were also developing radical and destructive technologies for which market research may not produce very reliable results.

The majority of our respondents (86\%) believe that a start-up has to focus its efforts on a defined niche market rather than trying to catch a wide market.

\section{Relationships with Customers}

The overall topic of Relationship with Customers received a score of 6.15. As Figure 3 shows, most of the parameters related to customer relationships are considered important. Open ended responses included; "the customers will define the success in the market and understanding their need and implementing their feedback is the only way to achieve a sellable product". Continuing sales were not seen as critical when a start-up is mostly looking for penetration. But, in the long run, "loyal customers who will buy the upgraded or other new products of the company are very valuable and are often a good way to attract new customers". Networking can be very useful for a start-up by assisting in expanding its own 
limited capabilities. Many of our respondents (86\%) noted that networking can be very useful.

Fig. 3: The main elements of relationship with customers

- Insert Fig. 3. about here please -

\section{Research \& Development}

$\mathrm{R} \& \mathrm{D}$, in general, received a score of 5.95 . Figure 4 shows that the important parameters identified are the team capability in general and the quality and durability of the product. Respondents noted that, "a poor product receives a bad word of mouth which disseminates quickly and customers will disappear". We also need to contextualise these comments because during the period of prosperity it was difficult to find adequate skilled technological manpower which may help explain why this parameter received a high score.

\section{Fig. 4: The main elements of $R \& D$}

\section{- Insert Fig. 4. about here please -}

\section{Marketing Staff and location}

As seen from figure 5, some $84 \%$ believe that the marketing team should incorporate a mix of Israeli and foreigners. There is no agreement over the preferred location of the marketing team, this depends on many features e.g. the industry, products, markets, and stage of the start-up. In general, $42 \%$ say it should be located in each main market; $35 \%$ want to see the 
team in Israel and $23 \%$ prefer to see the main marketing office located in the main target market.

Fig. 5: Origins and location of the marketing team

\section{- Insert Fig. 5. about here please -}

\section{Factors for Improvement}

We had also asked respondents about any specific areas of weakness or factors which might be improved upon. The following were mentioned most frequently:

- lack of skilled professional management (very often a poor balance between marketing and R\&D Management, with too much focus on technology);

- Marketing strategy shortcomings:

- Lack of understanding the market;

- Late marketing activity;

- Selection of a too small a market niche;

- Lack of planning about expansion into new markets/products;

- No continuous update of marketing plans and strategy, according to market events;

- General weaknesses in the marketing setup;

- Late and/or bad construction of the marketing department;

- Insufficient investment in sales and distribution channels.

- Adaptation of the product to the real market needs

- focus on the product instead of needs and

- developing too smart a product which does not meet marketing requirements. 
Our respondents suggested that success hinged upon the need to create a sound marketing strategy based on thorough investigation and knowledge of the market. Since formal market research, as conducted by research organizations, often does not provide usable results, more focused methods such as applying the expertise and experience of the core team and specific consultants have to be used to gain this applied knowledge. Respondents proposed the consideration, at an early stage as possible, of cooperation with customers and/or leading companies, but only after careful selection. Respondents mentioned that sometimes there is a need for a courageous decisions such as radical adaptations of the business plan to adjust to market needs and even painful decisions about top management, including the replacement of the founders. Some noted the weakness of the Israelis to seek advice, and suggest consulting and listening to experts to gain knowledge and experience. They propose exposing the idea quickly to market experts and to employ high level consultants.

As mentioned earlier, the point about a well defined and focused market niche was repeatedly mentioned. Some respondents mentioned the importance of a fit between investors and the start-up leaders. A much repeated theme was: focus, focus, focus! (on markets and products).

\section{Conclusions}

Our synthesis of the opinions of experts in the area of high-tech new venturing shows that marketing is critically important for success. The role of marketing becomes vital in young ventures located within small isolated economies. Such start-ups cannot become established, or grow, only in domestic markets and must therefore confront the urgent need to penetrate foreign markets. We identified that the key areas of marketing were; marketing strategy, the relationship with customers, $R \& D$ and location of the marketing team for international ventures. Some of the points emphasised by these experts and the implications included- 
- Penetration of international markets - This point is relevant for Israeli high-tech companies and for similar ventures located in small countries with small domestic markets. Israeli companies in general, and high-tech start-up in particular, lack management and marketing skills and experience. The combination of experience and skills is critical for international marketing.

- Focus - A start-up company always suffers from limited resources, thus focus is essential. The creative minds of the engineers and the new opportunities arising almost daily are a dangerous combination. Thus an ability to prioritize opportunities and to focus in terms of strategy, products and markets is crucial. Management has to lead the focusing efforts; sound and experienced marketing staff are required from the outset; and smooth communication between marketing and $R \& D$ is critical. However, too narrow a focus in a fast moving world is perilous, since markets might change their direction and needs, but a lack of focus in a situation of limited resources entails a much higher risk.

- Customer focus - For companies isolated from their main markets there is a tendency to ignore customer's needs. Marketing should involve potential customers at an early stage of the start-up activity.

- Networking and partnerships - It is unrealistic to expect a start-up to provide a complete technical product or solution. Start-ups should leverage the strengths of others by seeking cooperation with customers and/or major companies to overcome their deficiencies and lack of resources and to improve their access to markets. Although strategic partnerships with large companies are difficult and dangerous, because of the imbalance of power, tactical co-operations should be explored. 
- Planning and set up of the marketing activities - The respondents emphasized the need to plan marketing activities and provide for suitable marketing resources. Interestingly, Deloitte-Touche-Tohmatsu (2005) in their CEO survey, maintain that the biggest challenge in managing high-tech companies in 2004 was developing a strong sales and marketing strategy. Marketing has to be organized and staffed appropriately. Respondents suggested that a mix of local marketers and foreign marketers who understand the culture and buying behaviour of the targeted customers is a preferred solution. Deficiencies in marketing experience can be alleviated by consultants and networking capacities of the investors.

In essence, the major finding of our study was that whilst great technology and products are good, they do not necessarily lead to success. Focusing the limited resources in the proper direction while applying the concept of a well defined marketing strategy, focusing on customers, seems crucial for a high-tech start-up. This is a consequence of the volatility of the global high-tech world and becomes even more relevant for ventures requiring long arms to penetrate overseas markets.

\section{References}

Ali A. 1994. Pioneering versus incremental innovation, review and research propositions. Journal of Product Innovation Management, 11 (1): 46-61.

Audretsch, D.B., Carree, M.A., van Stel, A.J. \& Thurik, R. 2000. Impeded industrial restructuring: The growth penalty. Tinbergen Institute Discussion Paper 2000095/3, Tinbergen Institute.

Baker, W.H., Addams, H.L. \& Davis, B. 1993. Business planning and successful small firms. Long Range Planning, 26 (6): 82-88. 
Berry, M.M.J. 1996. Technical entrepreneurship, strategic awareness and corporate transformation in small high-tech firms. Technovation, 16: 487-498.

Burgel, O. \& Murray, G.C. 2000. The International market entry choices of Start-Up companies in High-Technology industries. Journal of International Marketing, 8 (2): $33-62$.

Carree, M.A. \& Thurik, R. 1997. Small firms and economic growth. Eramus University Rotterdam: Research Memorandum 9708.

Christensen, C.M. 1997. The innovator's dilemma. Boston, MA: Harvard Business School Press.

Christensen, C.M. \& Bower, J.L. 1996. Customer power, strategic investment, and the failure of leading firms. Strategic Management Journal, 17: 197-218.

Cooper, R.G. 1979. The dimension of industrial new product success and failure. Journal of Marketing, 43 (3): 93-103.

Cooper, R.G. 1994. New products: the factors that drive success. International Marketing Review, 11 (1): 60-76.

Cooper, R.G. \& Kleinschmidt, E.J. 1990. New product success factors: A comparison on "kills" versus successes and failures. $R \& D$ Management, 20 (1): 47-63.

Covin, J.G. \& Slevin, D. 1991. A conceptual model of entrepreneurship as firm behavior. Entrepreneurship, Theory and Practice, 16 (1): 7-25.

Cunningham, C. 2000. Technology Diaspora: Israeli high-tech industry faces a modern day exodus. Red Herring: Special Report on Israel, 82: 252-257. 
Davidow, W. 1986. Marketing high-technology. New York: The Free Press.

Davidow, W.H. 1988. The ascendancy of high-tech marketing. Electronic Business, 14 (10): 130-132.

Davis, J., Fusfeld, A., Scriven, E. \& Tritle, G. 2001. Determining a project's probability of success. Research-Technology Management, 44 (3): 51-62.

Day, G.S. 1999. Creating a market-driven organization. Sloan Management Review, 41 (1): 11-22.

Dhanani, S., O'Shaughnessy, N. \& Louw E. 1997. Marketing practices of UK high technology firms. Logistics Information Management, 10 (4): 160-166.

Dutta, S., Narasimhan O. \& Rajiv, S. 1999. Success in High-Technology Markets: Is Marketing Capability Critical? Marketing Science, 18: 547-558.

Dvir, D., Hauptman, A., Hougi, S., Tishler, A., Sokolov, M., Sharan, Y. \& Shenhar, A. 1997. Commercialization of military technologies in Israel. Tel Aviv: The Interdisciplinary Center for Technological Analysis and Forecasting and The Israel Institute of Business Research. (Hebrew).

Dvir, D. \& Tishler A. 1999. The changing role of the defence industry in industrial and technological development in Israel. Tel Aviv: The Israel Institute of Business Research. (Hebrew).

Easingwood, C. \& Koustelos A. 2000. Marketing High Technology: Preparation, Targeting, Positioning, Execution. Business Horizons, 43 (3): 27-34. 
Erickson, T.J., Magee, J.F., Rousel, P.A. \& Saad, K.N. 1990. Managing technology as a business strategy. Sloan Management Review, 31 (3): 73-78.

Frenkel, A., Reiss, T., Maital, S., Koschatzky K. \& Grupp, H. 1994. Technometric evaluation and technology policy: The case of biodiagnostic kits. Research Policy, 23: 281-292.

Gardner, D.M. 1990a. Are high-technology products really different? Faculty working paper, No 90-1706, Bureau of Economic and Business Research. Urbana, IL: University of Illinois at Urbana..

Gardner, D.M. 1990b. A strategic approach to high-technology marketing. Urbana, IL.: Faculty working paper, No 90-1707, Bureau of Economic and Business Research, University of Illinois at Urbana..

Gardner, D.M., Johnson, F., Moonkyu, L. \& Wilkinson, I. 2000. A contingency approach to marketing high-technology products. European Journal of Marketing, 34: 1053-1077.

Goldman, N. 2001. Israeli marketing: A work in progress. Israeli High-Tech Investor, February: 44-45.

Goupta, A. K., Raj, S. P., \& Wilemon, D. 1986. A model for studying R\&Dmarketing interface in the product innovation process. Journal of Marketing, 50 (2): 7-17.

Goupta, A.K. \& Wilemon, D. 1990. Improving R\&D - Marketing relations. $R \& D$ Management, 20: 277-289. 
Green, S.G. 1995. Top management support of R\&D projects: a strategic leadership perspective. IEEE Trans. Eng. Manage, 42 (3): 223-232.

Grossman, G.M. \& E. Helpman 1994. Endogenous innovation in the theory of growth. Journal of Economic Perspectives, 8 (1): 23-44.

Grunewald, J. \& Vernon, T.T. 1988. Pricing decision-making for High-Technology products and services. Journal of Business and Industrial Marketing, 3: 61-70.

Hashai, N. \& Almor, T. 2004. Gradually internationalizing 'born global' firms: an oxymoron? International Business Review, 13 : 465-483.

Jaworski, B. J. \& Kohli, A. K. 1993. Market orientation - antecedents and consequences. Journal of Marketing, 57 (3): 53-70.

Knight, G.A. \& Cavusgil, S.T. 1996. The born global firm: A challenge to traditional internationalization theory. Advances in International Marketing, 8: 11-26.

Kohli, A.K. \& Jaworski, B.J. 1990. Market orientation-the construct, research propositions, and managerial implications. Journal of Marketing, 54 (2): 1-18.

Kunda, G. 1992. Engineering Culture: Culture and Control in a High-Tech Organization. Philadelphia: Temple University Press.

Lerner, M. \& Avrahami, Y. 1999. Global entrepreneurship monitor: Israel executive report. Tel Aviv: Tel Aviv University.

Lerner, M. \& Avrahami, Y. 2002. Global entrepreneurship monitor: Israel executive report. Tel Aviv: Tel Aviv University. 
Lerner, M. \& Yeheskel, O. 2002. The performance of high-tech start-ups in Israel: Focusing on managerial variables. BKERC Conference, University of Colorado, Boulder, June 2002.

MacInnes, M. \& Helsop, L. 1990. Market planning in a high-tech environment. Industrial Marketing Management, 19 (2): 107-1116.

McDonald, M. 1989. Ten barriers to marketing planning. Journal of Marketing Management, 5 (1): 1-18.

Medcof, J.W. 1999. Identifying 'Super-Technology’ industries. Research Technology Management, 42 (1): 31-36.

Meier, A. 1998. Marketing young technological enterprises (German). Wiesbaden

Meldrum, M.J. 1994. Marketing High tech products: the emerging themes. European Journal of Marketing, 29(10): 45-58

Mohr, J. 2001. Marketing of high-technology products and innovations. Englewood Cliffs, N.J.: Prentice Hall.

Oakey, R., Rothwell, R. \& Cooper, S. 1988. The management of innovation in hightechnology small firms-Innovation and regional development in Britain and the United States. London: Pinter.

Oviatt, B. \& McDougall, P.P. 1994. Towards a theory of international new ventures. Journal of International Business Studies, 25 (1): 45-64.

Reeble, D. 1990. High-technology Industry. Geography, 75: 361-364.

Reingold, J. 2001. Can C.K. Prahad pass the test? Fast Company, 49: 108-115. 
Roberts, E.B. 1978. What do we know about managing R\&D. Research Management, 21: $26-30$.

Roberts, E.B. 1979. Stimulating technological innovation-Organizational approaches. Research Management, 22: 6-11.

Roberts, E.B. 1991a. High stakes for high-tech Entrepreneurs: Understanding Venture Capital Decision Making. MIT Management, 32 (2): 9-20.

Roberts, E. B. 1991b. Entrepreneurs in high-technology. New York: Oxford University Press.

Rosen, D.E., Schroeder, J. E. \& Purinton, E.F. 1998. Marketing high-tech products: lessons in customer focus from the marketplace. Journal of Consumer and Market Research, 98: 6-16.

Schumpeter, J. 1934. The theory of economic development. Boston, MA: Harvard University Press.

Slater, S.F. \& Narver, J.C. 1995. Market orientation and the learning organization. Journal of Marketing, 59 (3): 63-74.

Slater, S.F. \& Narver, J.C. 1998. Customer-led and market-oriented: Let's not confuse the two. Strategic Management Journal, 19: 1001-1006.

Slater, S.F. \& Narver, J.C. 1999. Market-oriented is more than being customer-led. Strategic Management Journal, 20 : 1165-1168.

Solow, R.M. 1970. Growth theory: An exposition. Oxford: Oxford University Press. 
Souder, W.E. 1977. An exploratory study of the coordinated mechanism between $R \& D$ and marketing as an influence on the innovation process. Final Report to the National Science Foundation, Pittsburgh: University of Pittsburgh, School of Engineering.

Souder, W.E. 1981. Disharmony between R\&D and marketing. Industrial Marketing Management, 10 (1): 67-73.

Steinberg, J. 1999. Taking the long view. Israel high-tech Investor, 5: 18-19.

Tadmor, Z. 1997. Israel towards unique historical golden opportunities. HighTechnion, 3: 16-17. (Hebrew).

Tapscott, D. 1996. The digital economy. New York: McGraw-Hill.

Traston, I., Sarusi, Y., Kochavi, D., Zisapel J. \& Ayalon, E. 2002. The technology industry as a growth lever. Working paper for the Herzeliya Conference, December 2002.

Traynor, K. \& Traynor, S. 1994. Efficacy of strategic and promotional factors on the sales growth of high-tech firms. IEEE Transactions on Engineering Management, 41 (2): 126-134.

Traynor, K. \& Traynor, S. 1997. Degree of innovativeness and marketing approaches used by high-tech firms. International Journal of Technology Management, 14: $238-247$.

Traynor, K. \& Traynor, S. 2004. A comparison of marketing approaches used by high-tech firms: 1985 versus 2001. Industrial Marketing Management, 33: 457461. 
Von Hippel, E.A. 1978. Users as Innovators. Technology Review, 80: 30-39.

Wind, Y. 1981. Marketing and other business functions. Research in Marketing, Vol. V, Jagdish and N. Sheth (Eds.) Greenwich, CT: Jai Press.

Wind, Y. 1982. Product policy: Concepts, methods and strategy. New York: Addison-Wesley.

Yin, K.R. 2003. Case study research, design and methods. Applied Social Research Methods Series, London: SAGE Publications.

Young, H.C. 1973. Product development setting, information exchange and marketing-R\&D coupling. Ph.D. dissertation. Chicago, Ill.: Northwestern University.

\section{Internet sources}

Deloitte-Touche-Tohmatsu. 2005. 2004 Deloitte Technology Fast 500 EMEA CEO Survey. URL:

http://www.deloitte.com/dtt/cda/doc/content/2004\%20Fast\%20500\%20Winners \%20Booklet\%20FINAL-low\%281\%29.pdf

Global Entrepreneurship Monitor - GEM. 2003. URL:

http://www.gemconsortium.org/category_list.asp?cid=113

Israel Central Bureau of Statistics - ICBS. 2001. "Development of information communication technology in the last decade." URL: www.cbs.gov.il, status 28.3.2001.

Israel Export Institute. 2002. URL: www.export.gov.il. 
Schaul Chorev has earned his $\mathrm{PhD}$ at Pec's university in Hungary in 2005 and is an honorary research fellow at the Centre for Entrepreneurship at Aberdeen Business School, Robert Gordon University. Schaul received his BSc degree in Electrical Engineering from the Technion in Haifa, Israel in 1979 and his MBA degree from the University of Oregon in 1990. He has a long international working experience in Israel and overseas as an electronic engineer and in marketing of high- tech systems. His current research interests are primarily related to high-tech entrepreneurship with focus on marketing and strategies of high- tech start-ups.

Alistair R Anderson, is Professor of Entrepreneurship and Director of the Centre for Entrepreneurship at Aberdeen Business School, Robert Gordon University in Aberdeen, Scotland. After some 20 years of starting and running small businesses, his curiosity about entrepreneurial people drove him to study entrepreneurship. Unfortunately he found that rather than answering his questions, he simply found more that there were many more interesting questions! He is still trying to answer some of them, especially in the social realms of entrepreneurship. Current themes being explored are social capital, social constructions and associated topic areas. 


\section{Figure 1: The high-tech marketing elements and issues}

- Needs to be met by new technology?

- Changing needs in the future?

- Market adaptation of industry standards?

- Pace of innovation penetration?

- Size of potential market?
- New products functioning?

- Meeting delivery timetable?

- Vendor high quality service?

- Product/service side effects?

- New technology cannibalization?

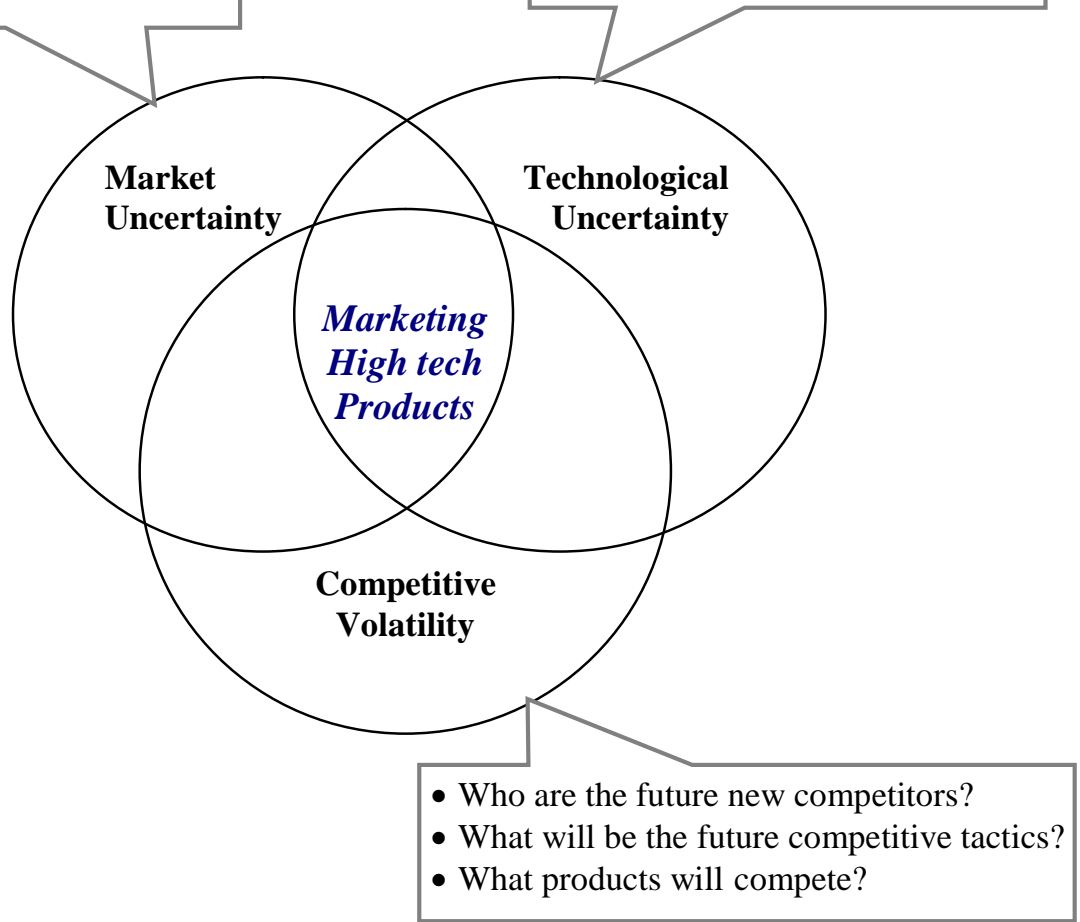

Source: Mohr, 2001 
Figure 2: The main elements of marketing strategy

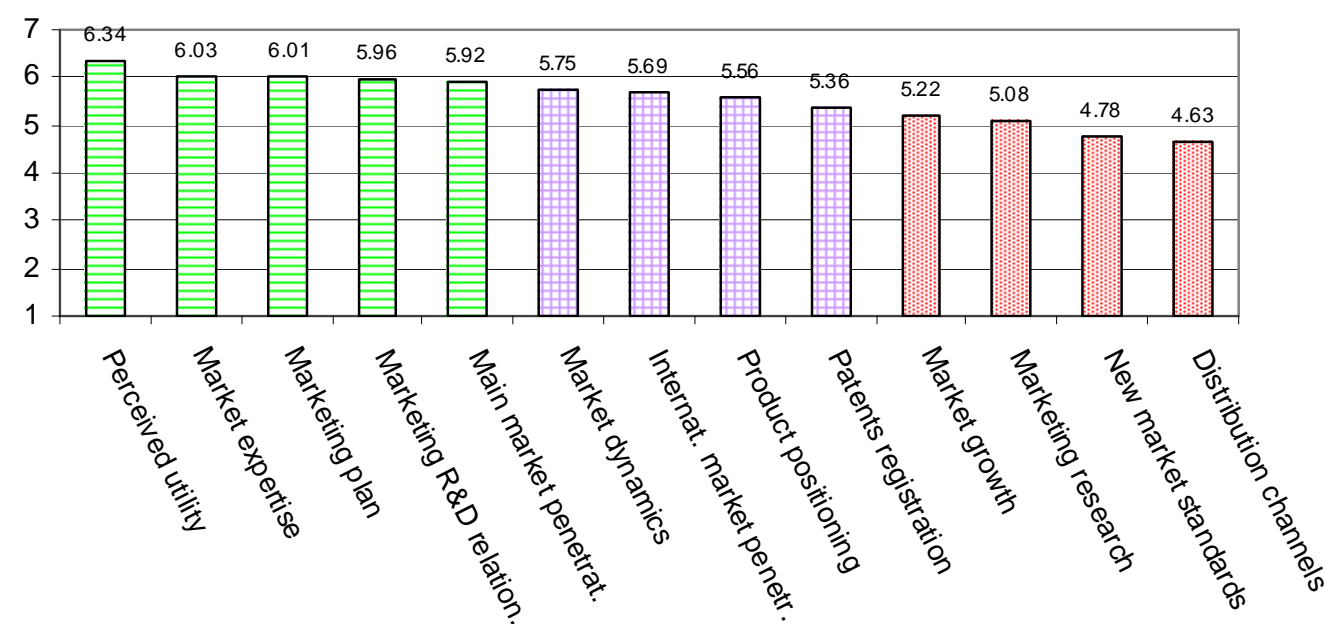

Figure 3: The main elements of relationship with customers

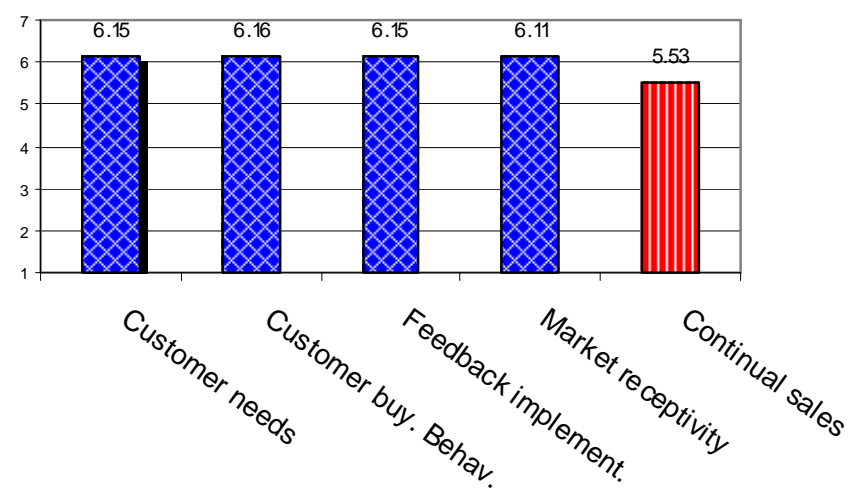


Figure 4: The main elements of $R \& D$

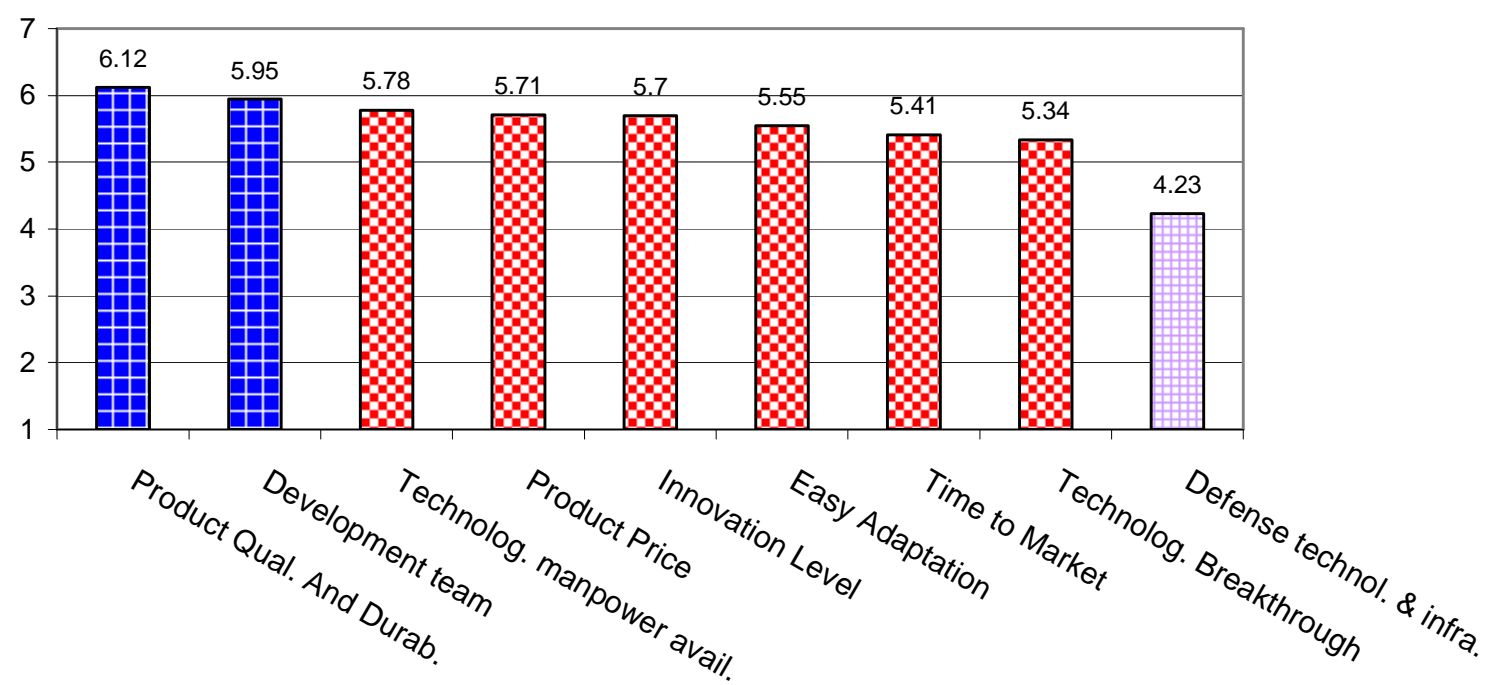

Figure 5: Origins and location of the marketing team

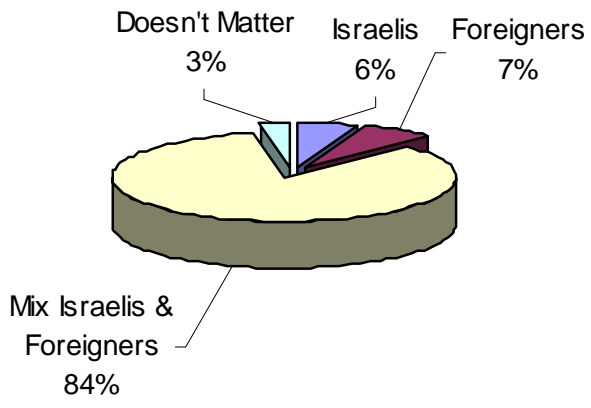

